\title{
ANTIBACTERIAL ACTIVITY OF ETHANOLIC EXTRACT BAWANG DAYAK (ELEUTHERINE BULBOSA (MILL.) URB) IN CREAM AGAINST PROPIONIBACTERIUM ACNES
}

\author{
SYAHRIDA DIAN ARDHANY*, SUSI NOVARYATIIN \\ Department of Pharmacy Faculty of Health Science, Muhammadiyah University of Palangkaraya, Central Kalimantan, Indonesia. \\ Email: chass501@gmail.com
}

Received: 05 December 2018, Revised and Accepted: 22 July 2019

\section{ABSTRACT}

Objective: The aims of this present study were to formulate antiacne cream consisting ethanolic extract of bawang dayak and evaluate antibacterial activity of cream on day 0 and day 7 to see stability activity and preparation.

Methods: Cream formula of bawang dayak was evaluated organoleptic characteristics, homogeneity, pH, adhesion test, dispersion test, and in vitro antibacterial against Propionibacterium acnes.

Results: The results of evaluate cream homogeneity were F3 and F4 on day 7 separate and non-homogen but all formula pH suitable for topical application. On day 0, F1 and F2 shown antibacterial activity in category weak activity, F3 and F4 in category moderate activity, while on day 7 all formula have antibacterial activity in category weak activity.

Conclusion: All cream formula potentials inhibit against $P$. acnes but this research must be improved both of preparation and stability activity.

Keywords: Acne vulgaris, Bawang dayak, Cream, Eleutherine bulbosa, Propionibacterium acnes.

(C) 2019 The Authors. Published by Innovare Academic Sciences Pvt Ltd. This is an open access article under the CC BY license (http://creativecommons. org/licenses/by/4. 0/) DOI: http://dx.doi.org/10.22159/ijap.2019.v11s5.T0020

\section{INTRODUCTION}

Acne vulgaris is one of the problems experienced by teenagers and adults because in this modern era, physical appearance is one of the most important things that must be considered. Acne is not a serious disease, but it can lead depression and loss of confidence. There are many causes of acne such as hormone level, fat or oil in skin, and a bacterium like Propionibacterium acnes [1]

Many cosmetic products that offer to improve acne problems, nature also provides a solution to these [2]. Bawang dayak is one of traditional medicines in Central Kalimantan. Based on research before, extract ethanol of bawang dayak can inhibit $P$. acnes, so in this research, ethanol extract was made in cream formulation to improve the efficiency of using traditional medicine.

\section{METHODS}

\section{Collection of plant}

Fresh plant materials, bulbs $(20 \mathrm{~kg}$ ) of bawang dayak (Eleutherine bulbosa (Mill.) Urb) were procured from farmer cultivation in Sei Gohong, Bukit Batu Palangka Raya Central Kalimantan.

\section{Preparation of plant extracts}

The plant materials were dried under the sun for 5-7 days. The dried plant materials were crushed by grinder. The powder of the plant materials was extracted with $96 \%$ ethanol using perkolator, and once process was finished, all extracts were concentrated in a rotary evaporator.

\section{Formulation preparation}

The formulation components used are listed in Table 1. The components consist of oil soluble (stearic acid, Adeps lanae, and paraffin liquid) and water soluble (TEA, nipagin, and aquadest). Each solution - oil soluble and water soluble - heated up to $55^{\circ} \mathrm{C}$ until melts. Ethanolic extract of bawang dayak dissolved in aquadest, then put into water soluble and stir until homogenous in mortar, oil soluble add gradually, stir until the cream base was formed. The last add oleum roses and stir ad homogenous.

\section{Evaluation of cream}

Organoleptic properties

The cream was observed for color, odor, and appearance.

\section{Homogeneity observed}

The particles size was observed on the slide to find the coarse particles. Preparations should show a homogeneous composition and no visible coarse grains [3].

\section{PH measurements}

Determining $\mathrm{pH}$ of the preparation is done using $\mathrm{pH}$ meter [4].

\section{Dispersion test}

Cream with $0.5 \mathrm{~g}$ was placed in the middle of a round glass scale. Round glass which has been weighted placed thereon and left for 5 min. After that followed with $50 \mathrm{~g}$ load, let stand for $1 \mathrm{~min}$ and record the diameter of the spread cream, did the same thing with $100 \mathrm{~g}$ and $150 \mathrm{~g}$ [5].

\section{Adhesion test}

A total of $0.5 \mathrm{~g}$ of preparation were spread on the disc glass, on top of it, other glass object placed and pinned under $1 \mathrm{~kg}$ load for $1 \mathrm{~min}$. Then, disc glass mounted on test equipment, load is released, and the time was recorded up to the second object of the glasses falling off [5].

Evaluation of antibacterial activity by zone of inhibition by well diffusion method

Ethanolic extract of bawang dayak was evaluated for in vitro antibacterial activity against propionibacterium acnes using the disc diffusion method with different concentrations (F1=5\%, F2 $=10 \%$, $\mathrm{F} 3=15 \%$ and $\mathrm{F} 4=20 \%$ ) of extract bawang dayak in a cream formula. 
Table 1: Various cream formula of ethanolic extract bawang dayak

\begin{tabular}{llll}
\hline Materials & F1 & F2 & F3 \\
\hline Extract ethanol of bawang dayak & $5 \%(1250 \mathrm{mg})$ & $10 \%(2500 \mathrm{mg})$ & $15 \%(3750 \mathrm{mg})$ \\
Ol. Rosae & $12 \mathrm{gtt}$ & $12 \mathrm{gtt}$ & $12 \mathrm{gtt}$ \\
Oily phases (mg) & & & $20 \%(5000 \mathrm{mg})$ \\
$\quad$ Stearic acid & 5000 & 5000 & 5000 \\
$\quad$ Adeps lanae & 750 & 750 & 750 \\
$\quad$ Paraffin liquid & 6250 & 6250 & 6250 \\
Aqueous phase (mg) & 375 & 375 & 375 \\
$\quad$ Triethanolamine & 25 & 2500 & 25 \\
$\quad$ Nipagin & 25,000 & 25,000 & 375 \\
$\quad$ Aquadest ad & & 25,000 \\
\hline
\end{tabular}

Table 2: Organoleptic appearance of various cream formula bawang dayak

\begin{tabular}{clll}
\hline Observation & Color & Odor & Appearance \\
\hline Day 0 & & & \\
F1 & Brown (+) & Significant (+++) & Semi-solid \\
F2 & Brown (++) & Significant (+++) & Semi-solid \\
F3 & Brown (+++) & Significant (++++) & Semi-solid \\
F4 & Brown (+++) & Significant (++++) & Semi-solid \\
Day 7 & & & \\
F1 & Brown (++) & Significant (+++) & Semi-solid \\
F2 & Brown (+++) & Significant (+++) & Semi-solid \\
F3 & Brown (++++) & Significant (++++) & Semi-solid \\
F4 & Brown (++++) & Significant (++++) & Semi-solid \\
\hline
\end{tabular}

+: Weak, ++: Moderate, +++: Strong, ++++: Very strong

Table 3: Homogeneity test of various cream formula bawang dayak

\begin{tabular}{cl}
\hline Observation & Result \\
\hline Day 0 & \\
F1 & Homogen \\
F2 & Homogen \\
F3 & Homogen \\
F4 & Homogen \\
Day 7 & \\
F1 & Homogen \\
F2 & Homogen \\
F3 & Non-homogen \\
F4 & Non-homogen \\
\hline
\end{tabular}

Table 4: Adhesion test of various cream formula bawang dayak

\begin{tabular}{ll}
\hline Observation & Adhesion (seconds) \\
\hline Day 0 & \\
F1 & 4.24 \\
F2 & 4.67 \\
F3 & 4.85 \\
F4 & 4.55 \\
Day 7 & \\
F1 & 2.17 \\
F2 & 2.76 \\
F3 & 2.93 \\
F4 & 2.43 \\
\hline
\end{tabular}

The bacterial isolates were subcultured into a nutrient. The 24-hourold bacterial culture was standardized using McFarland standard $\left(10^{6} \mathrm{CFU} / \mathrm{mL}\right.$ of $0.5 \mathrm{McF}$ arland standard). Mueller-Hinton agar (MHA) was used for bacteria bioassay. MHA was prepared by dissolving $38 \mathrm{~g}$ in $1000 \mathrm{ml}$ of distilled water and brought to boil to completely dissolve. Sterilization was achieved by autoclaving at $121^{\circ} \mathrm{C}$ for $15 \mathrm{~min}$ [6].

MHA plates were prepared and bacterial strains were inoculated by cotton swab, and then, antibiotic and cream with various concentrations of extract bawang dayak applied in it. The plates were incubated at $37^{\circ} \mathrm{C}$
Table 5: Dispersion test of various cream formula bawang dayak

\begin{tabular}{cllll}
\hline Observation & First $\mathbf{( c m )}$ & $\mathbf{5 0} \mathbf{g}(\mathbf{c m})$ & $\mathbf{1 0 0} \mathbf{g}(\mathbf{c m})$ & $\mathbf{1 5 0} \mathbf{g} \mathbf{( c m})$ \\
\hline Day 0 & & & & \\
F1 & 3.56 & 5.22 & 5.72 & 6.20 \\
F2 & 3.03 & 3.49 & 3.78 & 4.07 \\
F3 & 3.80 & 4.53 & 5.06 & 5.40 \\
F4 & 3.36 & 4.05 & 4.49 & 4.93 \\
Day 7 & & & & \\
F1 & 4.04 & 4.52 & 4.98 & 5.41 \\
F2 & 3.43 & 4.20 & 4.43 & 4.93 \\
F3 & 3.86 & 4.48 & 4.97 & 5.15 \\
F4 & 3.27 & 3.51 & 4.04 & 4.38 \\
\hline
\end{tabular}

Table 6: PH test of various cream formula bawang dayak

\begin{tabular}{cll}
\hline Observation & pH & Result $(\mathbf{p H}=\mathbf{4 . 5 - 6 )}$ \\
\hline Day 0 & 6 & Qualified \\
F1 & 6 & Qualified \\
F2 & 6 & Qualified \\
F3 & 6 & Qualified \\
F4 & & \\
Day 7 & 5.7 & Qualified \\
F1 & 6 & Qualified \\
F2 & 6 & Qualified \\
F3 & 6 & Qualified \\
F4 &
\end{tabular}

Table 7: Zone of inhibition of clindamycin

\begin{tabular}{lll}
\hline $\begin{array}{l}\text { Concentration of } \\
\text { clindamycin (\%) }\end{array}$ & Zone of inhibition $\mathbf{( m m )}$ & Result \\
\hline 0.5 & 25.53 & Strong activity \\
1 & 25.43 & Strong activity \\
2 & 27.33 & Strong activity \\
4 & 32.83 & Strong activity \\
\hline
\end{tabular}

Table 8: Zone of inhibition of various cream formula bawang dayak

\begin{tabular}{cll}
\hline Various cream & Zone of inhibition $\mathbf{( m m )}$ & Result \\
\hline Day 0 & & \\
F1 & 7.83 & Weak activity \\
F2 & 9.53 & Weak activity \\
F3 & 12.47 & Moderate activity \\
F4 & 12.53 & Moderate activity \\
Day 7 & & \\
F1 & 7.00 & Weak activity \\
F2 & 8.20 & Weak activity \\
F3 & 9.60 & Weak activity \\
F4 & 9.83 & Weak activity \\
\hline
\end{tabular}

for $24 \mathrm{~h}$, and the zone of inhibition was measured [7] and recorded later on. 


\section{RESULTS AND DISCUSSION}

\section{Evaluation test of cream formula}

Organoleptic appearance

The results of organoleptic test on day 0 showed that F1 had a lighter brown color than other formulas, it caused the concentration of ethanolic extract bawang dayak less concentration than other formulas. On day 7, all formulations became darker than before, this was probably due to ethanolic extract of bawang dayak content antioxidant compound. The odor of F3 and F4 on day 0 has sharper odor than F1 and F2, it caused concentration of ethanolic extract, but the odor has no change on the day 7 (Table 2 and Fig. 1).

\section{Homogeneity observation}

The observation of cream bawang dayak showed on day 0 all formulation homogen, but day 7, F3 and F4 showed separation phase between the oil phase and the water phase (Table 3 ).

\section{PH observation}

The $\mathrm{pH}$ observation showed all cream formula of bawang dayak around 6 on day 0 and day 7 (Table 6). The $\mathrm{pH}$ that suitable for topical application is same with $\mathrm{pH}$ of skin, between 4.5-6 [8].

\section{Dispersion test}

The dispersion test adding and without adding weight has an average of more than $3 \mathrm{~cm}$ to all creamy formula both on day 0 and day 7 (Table 5).
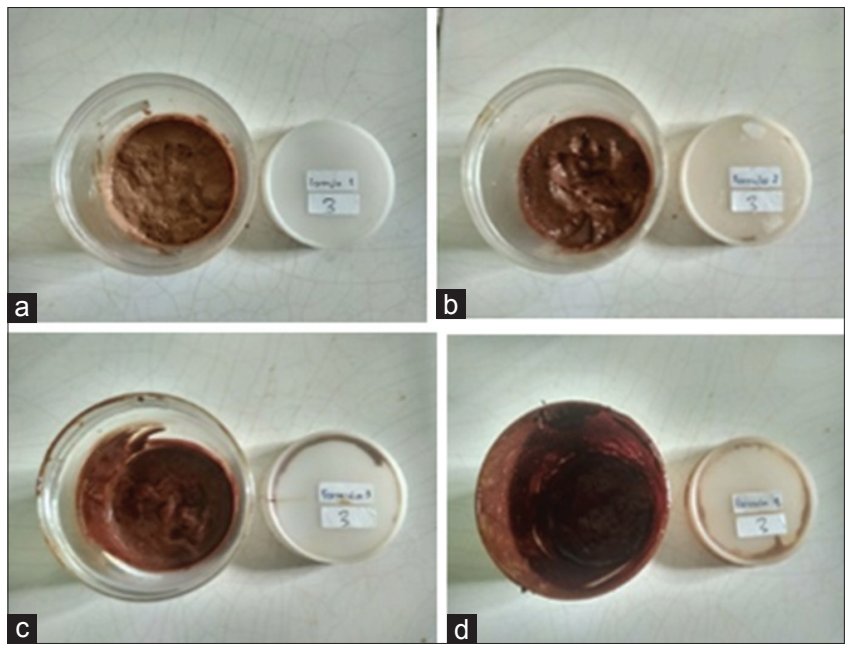

Fig. 1: Various cream formula ethanolic extract of bawang dayak; (a) F1, (b) F2, (c) F3, (d) F4

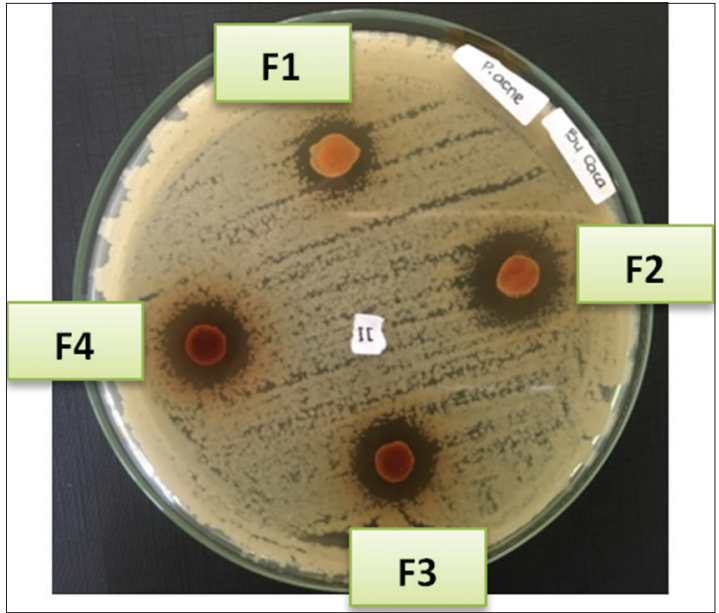

Fig. 2: Zone of inhibition all cream formula ethanolic extract of bawang dayak day 0
Adhesion test

Adhesion test of cream on day 0 was more than $4 \mathrm{~s}$ and time of adhesion decrease on day 7 (Table 4)

\section{Antibacterial activity}

The antibacterial activities can be classified into three levels: Weak activity (inhibition zone lower than $12 \mathrm{~mm}$ ), moderate activity (inhibition zone between 12 and $20 \mathrm{~mm}$ ), and strong activity (inhibition zone higher than $20 \mathrm{~mm}$ ) [9]. The inhibitory test results on day $0 \mathrm{~F} 1$ have $7.83 \mathrm{~mm}$ inhibition zone (weak activity), F2=9.53 $\mathrm{mm}$ (weak activity), $\mathrm{F} 3=12.47 \mathrm{~mm}$ (moderate activity), and $\mathrm{F} 4=12.53 \mathrm{~mm}$ (moderate activity), while all formula which stand until 7 days have decrease zone of inhibition in category weak activity (Table 8 and Figs. 2 and 3). Inhibition zone decrease on day 7 may be caused storage not in cool area like in refrigerator, so it was needed develop research further. This research showed that all formula with different concentration of ethanolic extract bawang dayak potential inhibit $P$. acnes that caused acne vulgaris although zone of inhibition smaller than clindamycin as positive control (Table 7 and Fig. 4).

Inhibition of all formula against $P$. acnes because ethanolic extract of bawang dayak contains secondary metabolites such as alkaloid, flavonoid, tannin, and saponin that can be potential has antibacterial effect against $P$. acnes [10]. Research about bawang dayak with the same type of plant specifically E. bulbosa parallel with research that conducted in India that stated bawang dayak has significant antibacterial activity [11].

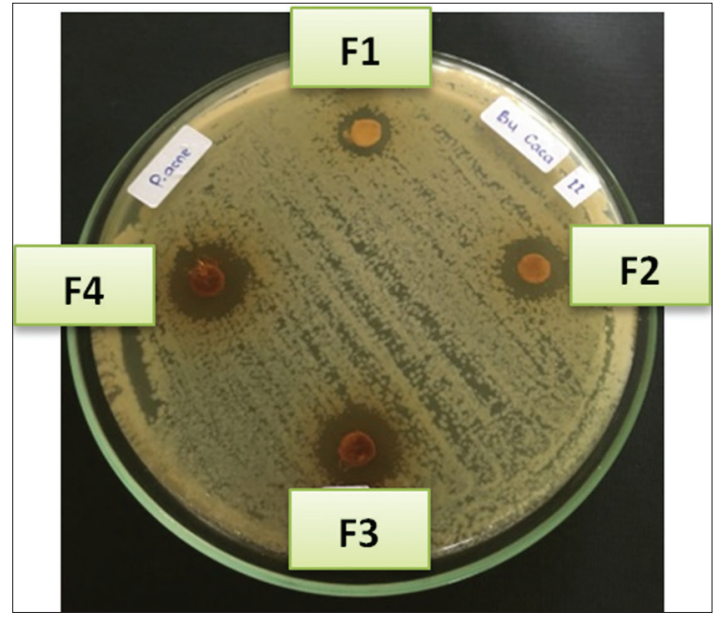

Fig. 3: Zone of inhibition all cream formula ethanolic extract of bawang dayak day 7

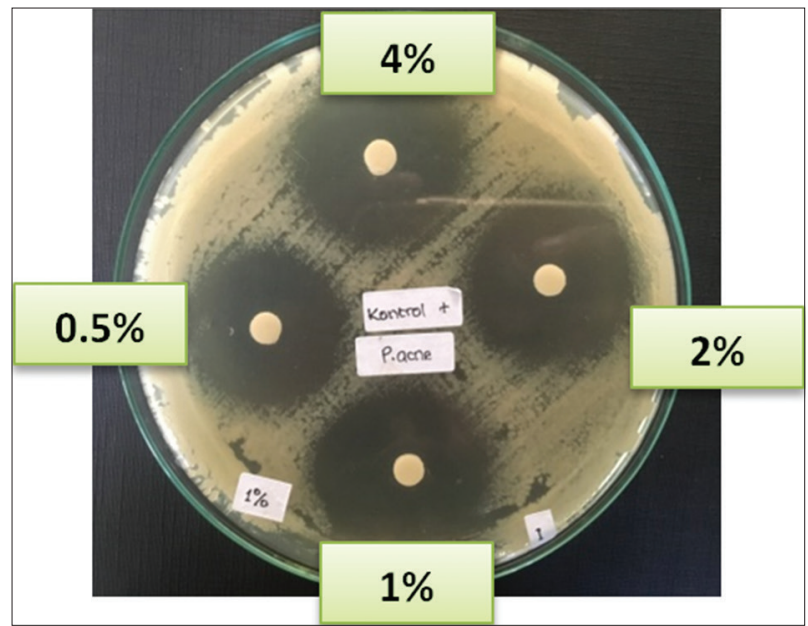

Fig. 4: Zone of inhibition clindamycin 


\section{CONCLUSION}

Extract ethanolic of bawang dayak in all cream formula potential inhibits $P$. acnes, but inhibitory ability decreases on day 7 . This research must be developed such as cream formula and improve effectiveness and combination with another material, so as the formula not separate and the effectivity is stable.

\section{ACKNOWLEDGMENT}

The authors wish to thank the Program Bantuan Seminar Luar Negeri Ditjen Penguatan dan Pengembangan, Kemenristekdikti of Indonesia to facilitate to the $4^{\text {th }}$ International Conference on Pharmacy and Pharmaceutical Science 2019 in Tokyo, Japan.

\section{REFERENCES}

1. Eshtiaghi MN, Kuldikole J. Formulation of anti acne cream containing natural antimicrobials. Int Res J Pharm 2013;4:20-5.

2. Waghmare PR, Kakade PG, Takdhat PL, Nagrale AM, Thakare SM, Parate MM. Turmeric as medicinal plant for the treatment of acne vulgaris. PharmaTutor 2017;5:19-27.

3. Nazliniwaty, Arianto A, Rizky AN. Formulation and anti-aging effect of cream containing breadfruit (Artocarpus altilis (Parkinson) Fosberg) leaf extract. Int J Pharm Res 2016;9:524-30.

4. Awad El-Gied AA, Abdelkareem AM, Hamedelniel EI. Investigation of cream and ointment on antimicrobial activity of Mangifera indica extract. J Adv Pharm Technol Res 2015;6:53-7.

5. Safitri FW, Syahreza A, Farah HS, Satrio BM, Hadi SI. Antioxidant activities and antioxidant cream formulation of corn silk (Zea Mays L) extract. Sains Medika 2016;7:64-9.

6. Mhatre J, Smita N, Shraddha K. Formulation and evaluation of antibacterial activity of a herbal ointment prepared from crude extracts of Aegle marmelos, (BAEL). Int J Pharm Pharm Sci 2014;6 Suppl 2:575-9.

7. Bhalodia NR, Shukla VJ. Antibacterial and antifungal activities from leaf extracts of cassia fistula 1.: An ethnomedicinal plant. J Adv Pharm Technol Res 2011;2:104-9.

8. Mali AS, Karekar P, Yadav AV. Formulation and evaluation of multipurpose herbal cream. Int J Sci Res 2015;4:5-611.

9. Shahbazi Y. Antibacterial and antioxidant properties of methanolic extracts of apple (Malus pumila), Grape (Vitis vinifera), Pomegranate (Punica granatum L.) and common Fig (Ficus carica L.) fruits. Pharm Sci 2017;23:308-15.

10. Ihsan EA. A chemotherapeutic efficacy of some antibiotics and Punica grantum L. Extracts againts Propionibacterium acnes isolated from acne vulgaris cases. Med J Islam World Acad Sci 2014;22:139-44.

11. Padhi L, Panda SK. Antibacterial activity of Eleutherine bulbosa against multidrug-resistant bacteria. J Acad Med 2015;5:53-61. 